DOI https://doi.org/10.36059/978-966-397-113-1/26-46

\title{
FINANCIAL CONTROL IN THE FINANCIAL MANAGEMENT SYSTEM
}

\section{Bortnyak V. A.}

\section{INTRODUCTION}

Any financial performance process becomes meaningless if a strategy to control it is not defined and implemented based on objectives consistent with the current state of the company and its upcoming projects.

Financial control has now become an essential part of any company's finances. Hence, it is very important to understand the meaning of financial control, its objectives and benefits, and the steps that must be taken if it is to be implement correctly. Financial control may be construed as the analysis of a company's actual results, approached from different perspectives at different times, compared to its short, medium and long-term objectives and business plans.

These analyses require control and adjustment processes to ensure that business plans are being followed and that they can be amended in the event of anomalies, irregularities or unforeseen changes. The accountabilities of Treasury Board, the Minister of Finance, deputy ministers, executive financial officers, the Comptroller General and central agencies are stated, along with supporting policy. Government's approach to control and risk is updated from a traditional input focus to broader measures of performance and achievement of objectives.

The role of the Financial Management Branch, Office of the Comptroller General, in maintaining the Core Policy and Procedures Manual and developing financial management policy is covered, as are the responsibilities of other central agencies by subject area in an appendix table.

\section{General and Financial Management}

The management principles for government's operating framework are: resource allocation decisions made during the budget process communicate the government's priorities; government and ministry goals and objectives must be communicated clearly to the public and staff 
throughout the hierarchy to ensure that all staff are working toward the same ends; assignment of responsibilities to minimize duplication of tasks and to ensure that someone is responsible for completing each function; staff who have been assigned responsibilities are given the authority to carry them out. Statutes grant authority to ministers and deputy ministers, and the authority is delegated throughout the organization; and individuals are held accountable for their stewardship after objectives have been established, responsibility assigned, authority delegated and resources allocated to individuals ${ }^{1}$.

The key components of the government's financial management framework include: legislation, regulations, policies and procedures; financial planning and budgetary control; systems and internal controls; delegation of authorities and responsibilities; adherence to standards; and holding individuals and organizations accountable for erformance.

Government's approach to the broad area of control has evolved with new demands for enhanced governance and has moved beyond traditional financial and general management control. In any organization, the essence of internal control is purpose, commitment, capability and monitoring. This is embodied in a redefined management and comptrollership for government.

Government resources, structures, systems, processes and culture all support management and staff in achieving objectives. Control can assist in monitoring performance by providing reliable information on measures used, which may lead to further management decisions or actions. However, control cannot prevent the taking of decisions that are, in retrospect, flawed. There are inherent limitations even though due care and diligence may have been exercised. Risk assessments are necessary in making choices in the face of uncertainty, because of the possibility of adverse consequences from those choices.

Treasury Board acts as a committee of the Executive Council in matters relating to: government management practices; government financial management and control, including expenditures and assets; evaluation of government programs as to economy, efficiency and effectiveness; government personnel management; and other matters referred to it by the Executive Council.

\footnotetext{
Багрінець С. Я. Діяльність міжнародних державних установ при здійсненні державного фінансового аудиту // Актуальні проблеми економіки. 2018. № 8. С. 321-334
} 
In addition, Treasury Board may make regulations or issue directives respecting: the planning, management and reporting of capital expenditures by government and government bodies and accounting policies and practices for the government reporting entity, and the form and content of documents required to be made public.

The Minister of Finance is responsible for: the management and administration of the Consolidated Revenue Fund; oversight of revenues and expenditures; government fiscal policy and any other financial matter not assigned to Treasury Board or to any other person.

The Minister of Finance is also the chair of Treasury Board.

Deputy Ministers, on behalf of their respective ministers, are responsible for: supervising the management of the business and affairs of their respective ministries. Specific financial responsibilities are normally delegated, as appropriate, to assistant deputy ministers and to other executive, senior and financial officers. Deputy ministers review and approve matters related to ministry operations, strategic direction and organizational structure to ensure government and the public's best interests are served. Duties include: strategic planning, review of service plans and identification of inistry opportunities and challenges; approval of annual operating and capital budgets; review principal risks of the ministry and plans, systems and processes to manage such risks; oversight on the reliability and integrity of internal control and management information systems, and management practices and processes to ensure compliance with applicable policy and legislation; monitoring senior executive performance and succession planning and communicating with stakeholders in a timely, accurate and effective manner ${ }^{2}$.

The Comptroller General is responsible for: government's financial management and administration policy and procedures; policies and procedures for maintaining the central accounts of government; preparing the Public Accounts and other financial statements and reports required by Treasury Board or the Minister of Finance; direction and coordination of financial management and administration policy and procedures, control and reporting systems and the approval of ministry financial organizational structures.

Treasury Board Staff are responsible for: providing the support to Treasury Board necessary to fulfill its statutory responsibilities, excluding

\footnotetext{
${ }^{2}$ Богуславська В. С. Внутрішній контроль: міжнародна правктика // Вісник ЖДТУ. - Серія: Економічні науки. 2017. № 2. С. 84-92
} 
those specific duties assigned by statute or delegation to other central agencies such as the Office of the Comptroller General and the BC Public Service Agency.

Central Agencies such as Shared Services BC, the BC Public Service Agency and the Chief Information Office are responsible for coordinating government-wide activities in specific areas under the authority of different statutes and authorities.

Ministry and agency systems of financial administration must integrate and be fully compatible with government-wide systems to ensure a cohesive framework for overall financial management and control. Ministries must establish, maintain and operate systems of financial administration that are consistent with statutes, regulations, policy and directives. Deputy ministers must ensure staff that are assigned responsibilities for program delivering, including financial administration, complete their responsibilities in accordance with government policy ${ }^{3}$.

Deputy ministers must delegate authority for ministry systems of financial administration to an executive financial officer, or to another officer depending on the size, structure and activities of the organization. This officer must be referred to as the chief financial officer and must report to an executive financial officer. Executive financial officers are accountable for the overall performance and effectiveness of ministry financial administration systems, and in most cases, have responsibility for personnel, data processing and general administrative services.

Responsibility centre managers must manage the human, physical and financial resources allocated to them for achieving their program objectives. Ministries must ensure that responsibility centre managers are clearly identified in their organizational structure and approve their signing authorities. Financial systems, processes and procedures related to a ministry's system of financial administration are to be clearly defined, documented and communicated to all levels within the ministry.

Ministries must periodically review their financial administration systems for compliance with policy, best practice improvements and to ensure activities are carried out efficiently and effectively. Responsibility centre managers and their subordinate staff are subject to the functional direction provided, on behalf of the deputy minister, by executive and chief financial officers in matters related to the financial administration

\footnotetext{
${ }^{3}$ Вишнівська В. А. Організація міжнародного контролю: Монографія. К.: Поро, 2018. 256 с.
} 
and control. Personnel charged with functional responsibilities must have the requisite qualifications and experience to assure an overall quality of management and financial administration. Professional development and training will be required as necessary to maintain standards ${ }^{4}$.

Position descriptions for personnel must reflect key functions and activities for the organization, and accurately describe the knowledge, skills and abilities required for the position. Deputy ministers, executive financial officers and, where applicable, chief financial officers will be subject to the functional direction and guidance of the Comptroller General in matters related to the administration and control of the government's system of financial administration. The Comptroller General must be part of selection processes in appointing chief financial officers.

The Comptroller General must review any proposals for the establishment of, or revision to, regulations under the Financial Administration Act. The Minister of Finance must approve all proposals for the establishment of, or revision to, Treasury Board Regulations prior to submission to Treasury Board (see Information and References, Regulations, Order in Councils and Directives).

The Financial Management Branch, Office of the Comptroller General, develops, issues and maintains the online Core Policy and Procedures Manual. Review and consultation with Treasury Board Staff, the Deputy Minister Committee, Assistant Deputy Ministers on Corporate Service Committee, Chief Financial Officer Council, and other central agencies, as appropriate, must precede the issuance of new policy. Ministries, central agencies and offices sponsoring amendments to policy must circulate the proposed policy change to the Office of the Comptroller General.

\section{Financial Systems and Controls}

Financial systems generate a significant amount of data and information, and are a vital component in managing the delivery of government services and in producing the Province of B.C. Public Accounts.

\footnotetext{
${ }^{4}$ Войдевич Н. О. Розвиток державного внутрішнього фінансового контролю в Україні // Проблеми підвищення ефективності інфраструктури: Збірник наукових праць. Вип. 28. К.: НАУ, 2017. С. $26-29$.
} 
Treasury Board has overall responsibility for government financial management and control in the province. On behalf of Treasury Board, the Office of the Comptroller General and Treasury Board Staff, Ministry of Finance prepare and release summary financial information, as well as, detailed information on ministries and agencies that make up the Consolidated Revenue Fund and the Government Reporting Entity.

Ministries are responsible for their financial systems and ensuring compliance with government policy and technology standards. The ministry Executive Financial Officer (EFO) or Chief Financial Officer (CFO) where delegated, has overall responsibility for implementation and operation of a financial system.

The Comptroller General is responsible for policy and direction for financial systems, and communication of standards and guidelines.

The Government Chief Information Officer is responsible for corporate information management and information technology policies and standards including architectures and information security.

Provincial Treasury is responsible for banking and financial transaction policies and standards, including approving and coordinating ministry acceptance of electronic payments.

Financial Information - for the purposes of this chapter, means the transactions or data produced or used in understanding, managing, and reporting on the financial aspects of an activity, and is not limited to accounting data. Financial information is relied on to make decisions of a financial nature.

Financial System - for the purposes of this chapter, means a significant system or process (e.g.: manual, automated, end-to-end, feeder, interfaced, central, including data and software applications) that produces or generates financial information ${ }^{5}$. For example, systems that:

- collect, maintain, process, transmit or report financial transactions;

- support internal and external financial report preparation, such as, cost and revenue information, financial statements, and the Public Accounts;

- assist ministries and central agencies with financial management, control, budgeting and forecasting.

Financial Risk and Controls Review (FRCR) - assesses and documents the adequacy of the designed controls for a new financial

\footnotetext{
5 Вуйців М.М. Розвиток функції контролю при впровадженні інтегрованих інформаційних систем // Актуальні проблеми економіки. 2018. № 4. С. 226-242.
} 
system (or a significant modification to an existing financial system or a system having a key financial component) with generally accepted financial control standards to prevent and reduce the risk of loss, error, misuse or fraud and to ensure conformity with accounting assertion criteria.

Payment Card Industry Data Security Assessment (PCI-DSA) - an assessment against the policies and standards established by Provincial Treasury for new or existing financial systems that accept payment cards.

Privacy Impact Assessment - an assessment conducted by a public body to determine if a current or proposed enactment, system, project, program or activity meets or will meet the requirements of the Freedom of Information and Protection of Privacy Act.

Security Threat Risk Assessment (STRA) - an information risk assessment process in a form approved by the Chief Information Security Officer, Information Security Branch.

Suite of Corporate Financial Systems - the core financial systems which support many of government's mission critical financial management business functions comprised of:

- the financial management and reporting system maintained by CAS, including the general ledger; data warehouse; budget and chart of accounts module; fixed asset module; accounts receivable module; iProcurement, purchase order, iExpenses and accounts payable modules; the corporate contract management module; the CAS Generic Interface; and the common interface for credit card payments.

- the Human Resource Management System, Time On Line and Corporate Human Resource Information and Payroll System maintained by Public Service Agency;

- the banking, cash, debt and investment systems maintained by Provincial Treasury, Ministry of Finance; and

- the revenue and tax collection systems maintained by Revenue Division, Ministry of Finance.

Ministries are responsible for determining the methodology to be used in the development of a financial system. The methodology must be consistent with government architectures and information management and information technology (IM/IT) policies and standards.

A financial system requires ministry approval prior to placement into production. Ministry EFO approval on the recommendation of the CFO, 
and Comptroller General acceptance of the FRCR report (Policy 6), is required to implement a new financial system or a significant enhancement to an existing financial system. Financial system documentation needs to support compliance and financial risk and controls assessment ${ }^{6}$.

Ministries must make use of, to the extent practicable, the suite of corporate financial systems or a component thereof, to process financial information so that core functionality is maximized and not duplicated. In addition, prior to developing any new financial system (or making significant modification to an existing financial system or a system having a key financial component) and/or submitting a funding request for same, ministries must collaborate with OCG1. This is to ensure that the proposed financial system or enhancement is warranted in addition to what is provided, or is capable of, by the suite of corporate financial systems.

Ministries must receive OCG endorsement before financial system development is substantially initiated or the funding request is advanced further in the budget approval process. The primary point of contact is between the ministry CFO and the Executive Director, Financial Management Branch, OCG.

Ministries must ensure that their financial information processes and financial systems have sufficient and comprehensive controls to prevent and reduce the risk of loss, error, misuse or fraud to an acceptable level. To this end, ministries must complete a pre-implementation FRCR for a new financial system (or a significant modification to an existing financial system or a system having a key financial component). The preimplementation FRCR must be initiated during system development and completed prior to implementation to production. Ministry resourcing for the FRCR should be identified in the development budget.

Qualified, independent and objective parties (internal or external to the ministry) are required to complete the FRCR, at the discretion of the ministry EFO or CFO, where delegated. For example, use of experienced ministry audit or in-house systems staff, such as, a professional accountant (CA, CMA, CGA) with IM/IT audit skills, or a Certified Internal Auditor (CIA) with IM/IT audit skills, or a Certified Information Systems Auditor (CISA) with financial audit skills for the review would

\footnotetext{
6 Гулько В.В. Модернізація державного фінансового контролю в Україні відповідно до європейського практики // Актуальні проблеми економіки. 2016. №1. С. 199-204.
} 
be appropriate, as long as the reviewer was not the system developer, operator, or central to the program area that will use the financial system. In a self-assessment situation, the FRCR should be endorsed by an external service provider or qualified independent ministry staff with the requisite financial and IM/IT audit skills ${ }^{7}$.

The ministry EFO, or CFO where delegated is responsible for approval of the pre-implementation FRCR report. The approved report must be provided to and accepted by the Comptroller General before the ministry implements the financial system to production. The primary point of contact is between the ministry CFO and the Executive Director, Financial Management Branch, OCG.

A post-implementation FRCR must be conducted by the ministry before the third year of operations to confirm that the financial system continues to support business requirements, any weaknesses have been addressed, and key financial controls continue to prevent and reduce the risk of loss, error, misuse or fraud.

Ministry assessment activities and workload for the postimplementation FRCR should be rationalized with those required of any other periodic assessment or assurance engagement.

The ministry EFO, or CFO where delegated is responsible for approval of the post-implementation FRCR report. The approved report must be provided to and accepted by the Comptroller General before the third operating year of the financial system has commenced. The primary point of contact is between the ministry CFO and the Executive Director, Financial Management Branch, OCG.

Ministries must ensure that payment transaction systems and processes are developed in compliance with Banking \& Cash Management Branch, Provincial Treasury's policies and standards.

A principal requirement is that people that manage access to, or administer, electronic commerce systems must receive periodic training on how to protect payment card data (refer to the PCI DSS - Resource Centre (government access only) for Security and Awareness Training government access only), as well as, participate in annual assessments coordinated by Banking \& Cash Management against the PCI Data Security Standard. In addition, any new outsourced payment system must be certified as PCI compliant by the EFO prior to deployment.

\footnotetext{
${ }^{7}$ Довбня В.Д. Внутрішній контроль: реалії часу: Монографія. Донецьк: УкрДон, 2013. 187 с.
} 
Refer to these Guidelines (government access only) for additional information on the corporate financial architecture when developing new financial systems to process payments. The guidelines are also intended to support engagement between ministries and OCG.

\section{Financial Risk and Controls Review}

Guidance on internal controls, FRCR completion, reporting and approval, and additional control examples are outlined below.

Effective internal controls support achievement of an organization's objectives. However, a one way or one size approach to designing and managing internal controls is not always realistic given the complexity of various government processes and systems to support them.

For a financial system, internal controls need to address key risks in the context of the overall business and environment in which it operates. The objective is to ensure an effective internal control regime for financial information and that it is consistent with the standards established for accounting assertions*. For example, assurances that financial transactions are properly authorized, financial records are properly maintained, assets are safeguarded, and that applicable legislation and policies are complied with.

To the extent possible, key controls over financial information and account balances should be automated. It is recognized that automation is not always possible and manual procedures, such as reconciliations and management reviews, may be necessary. It is expected that key automated and compensating controls will form an integral part of user acceptance testing, and their design will be confirmed as part of the $\mathrm{FRCR}^{8}$.

Financial information transferred from a ministry financial system to the CAS Financials system, whether detailed or summarized, must meet transaction criteria for: Occurrence: recorded transactions actually occurred; Completeness: all transactions that should be recorded are; Valuation/Accuracy: correct transaction values are recorded; Classification: transactions are recorded in the proper account; Authorization: recorded transactions are valid; Cut-off: transactions are recorded in the correct accounting period; For subsidiary ledgers maintained by ministries, the subsidiary financial system balances must meet criteria pertaining to account balances for: existence: asset and

\footnotetext{
${ }^{8}$ Ковальчук С.Т. Внутрішній контроль: роздуми щодо сутності // Вісник ЧДТУ. 2017. № 1. С. 11-17.
} 
liability balances exist, completeness: all valid asset and liability balances are recorded and can be reconciled to the CAS Financials system, valuation: asset and liability balances are included at correct amount.

The FRCR is a formal analysis of a financial system and the environment in which it operates using a risk-based approach. Key risk areas are identified and assessed along with the associated controls established by the internal control regime to mitigate risks. The assessment is supported by a scoping and risk rating exercise to determine whether the financial system includes adequate internal controls.

In relation to a financial system the following internal control areas need to be considered: business process controls -- include application controls. The scope of a FRCR needs to address material classes of financial transactions, account balances and summary financial information. Use quantitative and qualitative factors to determine whether or not the application supports material items. For example, review the dollar value of material transactions and the complexity of the accounting policies, or susceptibility of the process to error and fraud to determine the significance of the application/system and control objectives.

When the review of financial transactions/business processes for quantitative and qualitative factors is complete, overall significance and risk can be established. This is then used to determine the in scope financial transactions/business processes which need to be assessed by the FRCR.

General computer controls - include controls for system development, changes, access to programs and data, and continuity of operations, specifically business continuity, disaster and back-up recovery plans. In addition, the overall governance of the financial system and the definition and assignment of roles and responsibilities, including segregation of duties are considered. Refer to the COBIT ((the Control Objectives for Information and related Technology) is a framework or set of best practices for information technology management and has become a common standard for information technology related controls. COBIT provides users with a set of generally accepted measures, indicators, processes and practices to develop appropriate information technology controls. For additional information, refer to the ISACA website) control framework for detail information. 
For the in scope application/system, the general computer controls in place to support the application are identified. When completed a risk assessment for each unique control area can be established. The risk ratings assist in identifying the priority of the general computer controls for the application and the FRCR.

Assessment activities for FRCRs should be coordinated with other assessments required by legislation or policy including a Security Threat and Risk Assessment (STRA), Privacy Impact Assessment, and Payment Card Industry Data Security (PCI-DSA) assessments. The review and assessment activities involve systems or programs with similar operating environment and security concerns and will likely generate common control and risk management information.

The control objectives, assessed risks, key controls, residual risk, and final assessment comments need to be documented, preferably in matrix form (see the template in 13.4.3) to support the review and remedial of any weaknesses. While generic, completion of the matrix requires consideration of the business context and financial implications in relation to the control objectives and risks ${ }^{9}$.

A ministry self-assessment is acceptable when validated by an external service provider or qualified independent ministry staff with financial and IM/IT audit skills.

Ministry EFO sign off, or CFO where delegated, is required before the FRCR report is submitted to the Comptroller General. The FRCR report will also assist the $\mathrm{CFO}$ with ministry representations on financial reporting controls in relation to the Public Accounts

\section{Internal Audit}

Internal auditing is an independent, objective assurance and consulting activity designed to add value and improve the government's ability to meet its service goals and objectives. It uses a systematic and disciplined approach to evaluate and recommend improvements in the effectiveness of risk management, internal control, decision support and governance processes.

The internal audit function does not relieve ministry management of responsibility to establish and support an adequate internal control

\footnotetext{
9 Кулаковська Л.П. Практичний погляд на фінансовий контроль та фінансовий менеджмент // Економіка і підприємництво. 2016. № 4. С. 14-19.
} 
environment within their organization. It is ministry management's responsibility to plan, organize and direct the undertaking of sufficient controls to provide reasonable assurance that government goals and objectives will be accomplished in the most effective, efficient and economical manner.

The authority to undertake internal audits is derived from sections 4, 8 and 9 of the Financial Administration Act. Responsibility for the internal audit function within government has been delegated to the Office of the Comptroller General (OCG) and is administered by the Internal Audit and Advisory Services Branch (IAAS).

Cabinet: receives through Treasury Board, a presentation from IAAS on risks to the achievement of government's goals; provides guidance to Treasury Board on its priorities to assist IAAS in developing the Annual Corporate Audit Plan; receives through Treasury Board an Annual Corporate Audit Plan which responds to guidance provided; approves the Annual Corporate Audit Plan; receives through Treasury Board copies of all corporate and ministry audit reports prepared by IAAS, other than ad hoc and forensic audit reports; endorses Treasury Board recommendations for actions required to address significant issues arising through the corporate audit reports; receives through Treasury Board an annual report indicating the status of implementation of recommendations ${ }^{10}$.

Treasury Board: provides direction to IAAS on Cabinet's guidance, for inclusion in the annual audit planning process; receives the Annual Corporate Audit Plan prepared by IAAS based on direction received; receives all audit reports prepared by IAAS, other than ad hoc and forensic audit reports, and makes specific recommendations to Cabinet on actions arising from the audit reports; directs IAAS, through the Comptroller General, to examine and report on whether public money, as defined in the Financial Administration Act, has been disbursed for the purpose intended, and to examine the financial management of government corporations; receives an Annual Report from the Comptroller General which summarizes the effectiveness of financial management and administration across government.

Comptroller General: responsible for providing an effective Internal Audit function for government; directs IAAS to examine the disbursements of public monies and the financial management of

\footnotetext{
10 Марченко Д.М. Удосконалення організації внутрішнього фінансового контролю підприємств // Актуальні проблеми економіки. 2017. № 2. С. 163-171.
} 
government corporations, as requested by Treasury Board; directs IAAS to investigate and monitor loss incidents in government, where appropriate; provides an Annual Report to Treasury Board which outlines recommendations for improvements to financial management across government.

Deputy Ministers: provide input into the annual corporate risk assessment and audit planning processes; a committee of deputy ministers will be established to review an Annual Audit Plan for ministry-specific projects arising from the annual risk assessment. This committee will also receive copies of all ministry-specific audit reports; receive copies of corporate audit reports that impact their organization; will provide timely responses to corporate or ministry-specific audit reports that involve the deputy minister's accountability

Ministries: provide input into the annual risk assessment process and audit planning process; request IAAS to perform ad hoc services; report significant loss incidents, including suspicions of illegal activity, to the Comptroller General.

Internal Audit and Advisory Services Branch (IAAS): provides an independent and objective assessment of the operations of ministries, agencies, boards and commissions and advises on improvements resulting from internal audit activities; provides a continuum of services ranging from assurance regarding the effectiveness of internal controls and compliance to comprehensive assessments of program performance and information systems; provides ongoing support and advice to ministry management through the conduct of special investigations, performance reviews and consulting services that support core activities ${ }^{11}$.

\section{Corporate Compliance and Controls Monitoring}

The objective of the compliance and controls monitoring function is to work co-operatively with ministries and central agencies to provide a corporate monitoring mechanism to improve compliance with government core policy and to strengthen the financial and procurement control framework by: providing confidence that government payments are made in accordance with government core policy, including central directives, orders, and regulations; mitigating the risk of financial loss to government; reducing the cost of processing payments; and identifying and recommending systemic change to maintain and improve the overall control framework.

\footnotetext{
${ }^{11}$ Нєскородєв Ю.В. Методологічні аспекти фінансового контролю: Монографія. К.: Фотос, 2015. 403 с.
} 
The compliance and controls monitoring function is a centralized systematic, risk-based approach designed to promote accountability and monitor the prudent and proper use of public monies. The Branch's monitoring and review approach is based on the government's Enterprise Risk Management Model (government access only).

The scope of the compliance and controls monitoring function encompasses all government payments that may be selected at any time for the examination of accuracy and compliance with core policy, central directives, orders, and regulations. Payment review results and recommendations are reported back to ministries, central agencies, and the Office of the Comptroller General.

The corporate compliance and controls monitoring function does not replace the responsibility of ministries and central agencies in establishing, supporting and maintaining an adequate system of internal controls including a sufficient financial and procurement control framework.

The authority to undertake compliance and controls monitoring is derived from sections 8 and 9 of the Financial Administration Act. Responsibility for the monitoring function within government including compliance reporting and recommendations regarding non-compliance has been delegated to the Office of the Comptroller General (OCG) and is administered by the Corporate Compliance and Controls Monitoring Branch (government access only).

The Corporate Compliance and Controls Monitoring Branch is responsible for: reducing the cost of internal controls by implementing a risk based management approach; testing and reporting on government payments for compliance with core policy, central directives, orders and regulations; recommending improvements to government policy, training and systems to improve compliance through both targeted and systemic changes; identifying control weaknesses and assisting central agencies and ministries in strengthening the financial and procurement management framework; providing custom payment reviews and reports where warranted and maintaining branch policy and procedures (government access only) for the administration of compliance and controls monitoring ${ }^{12}$.

Ministries are responsible for: establishing, supporting and maintaining an adequate system of internal controls; following up on $\mathrm{CMB}$ recommendations and reporting back on corrective actions taken to reduce risk and improve compliance; collecting amounts owed to

\footnotetext{
12 Пожар Т.О. Роль фінансово-економічних методів державного фінансового контролю у забезпеченні бюджетної дисципліни // Актуальні проблеми економіки. 2011. № 8. С. 327-333.
} 
government identified in the review process and identifying ministry contact(s) for the receiving and conveying of requested documentation to support payments (government access only) selected for review.

\section{Budget and financial management}

Local governments, who have the competencies to effectively manage public finances, can better prioritize and allocate resources for social and economic needs.

On the contrary, corrupted, inefficient, or inadequate, public financial management may result in missed opportunities for growth and financial losses, reduced total investment and quality of infrastructure, underperformance of institutions, and a pervasive institutional corruption.

Poor planning practices that include failure to link policies, planning and budgeting, may contribute negatively to government performances and may foster corruptive behaviours on public financial management. In addition, many local governments still have weak or inadequate mechanisms for citizens to monitor government's performances on the financial field. With a poor control over expenditures and public goods, local officials may be involved in frauds, thefts and embezzlement.

In this framework, meaningful public oversight and participation in the formation of budgetary programs, as well as, making audit reports available to the public, could be beneficial to effectively restrain corruptive behaviours. Moreover, municipalities have to ensure, through all the stages of the budgetary processes, a reliable, transparent and comprehensive record of disbursements made, in order to promote accountability and identify irregularities.

An integrity risk assessment of budget and financial management and reporting, may identify some or all of the following integrity risk factors (the list is not limited):

Poor planning: Failure to link policy, planning and budgeting may contribute to poor budgeting outcomes. Inability to develop realistic forecasts may lead to non-transparent adjustments during budget execution. Inadequate funding of operations and maintenance may result in systems underperforming. Poor expenditure control may be exploited to gain a personal benefit (officials purchasing goods through the system for private use).

Missing nexus between budget as formulated and budget as executed. Inadequate accounts management creates possibilities for diversion of public funds to private accounts. Poor cash management allows fraud and theft of resources. Officials state inflated price regarding the value of a service to misappropriate cash. Officials do not record the transaction or 
full amount of the cash collected. Officials make unauthorized modifications to payroll database records for personal benefit. Officials state incorrect input details in processing payroll (i.e. number of days worked and overtime, leaves taken.) Salaries are paid to fictitious employees and accounts (,ghosts“" on the payroll).

Officials provide false information for the reimbursement of expenses. Officials make reimbursement claims based on improper bills. Improper verification of bills leads to excess payments.

Following the risk assessment, the local government may consider the following risk management strategies as development points to include:

Allow enough time to systematically provide the local assembly with all the financial and accounting documents needed for an informed vote on the budget, as well as on the approval of accounts.

Further to national regulations, introduce and implement a clear and comprehensive regulatory and operational framework for budget and fiscal management. Mechanisms for budgeting and policy formulation should be explicitly designed to reinforce coordination and cohesion in decision-making. Ensure that budget planning is based on reliable information. The integrity of fiscal information should be made subject to public and independent scrutiny.

Train all relevant staff to ensure they are aware of their responsibilities and acquire the necessary competence. Build and strengthen capacities for effective participation of all relevant staff in the budget process in all its phases. Pay attention to providing adequate capacities of heads of units that need to formulate their projected budgets

Through all stages of the budget process (formulation, approval, implementation and evaluation), provide timely local community with full, transparent and comprehensive information on the past, current, and projected fiscal activity of local government, specifying fiscal policy objectives, the macroeconomic framework, the policy basis for the budget and identifiable major fiscal risks. Ensure budget data is classified and presented in a user-friendly and simple way that enables policy analysis and promotes accountability.

Ensure appropriate participation (involvement) of citizens, NGOs, and other local stakeholders in the formulation of expenditure programs. Actively promote an understanding of the budget process by individual citizens and NGOs. Fiscal reporting should be timely, comprehensive, reliable, and identify deviations from the budget. Public financial documents cover budgets, in-year reports, mid-year reports, year-end reports and audit reports. Ensure availability and implementation of 
clearly and comprehensively specified procedures for the execution and monitoring of approved expenditures. Introduce a system in which any new expenditure proposal over a certain threshold should be approved by the local assembly. Ensure that there are appropriate supervision, delegation and approval processes for accounts management ${ }^{13}$.

Validate invoices with supporting documentation such as requisitions and purchase orders to help ensure that all payments are for legitimate goods and services.

Ensure that the financial management system systematically records all disbursements made, and allows them to be easily traced. Ensure regular, accurate capture and reconciliation of all transactions. Information on and lists of payments made over a certain specified threshold should be publicly available. A reliable system and adequate mechanism shall be set to trace budget expenditures at planned appropriate intervals (i.e. on a monthly basis) to allow better analysis of the budget implementation dynamics. Monitor and review by a finance committee, or equivalent, of the monthly financial performance, budgets and budget transfers, allocations, financing of projects and significant financial transactions to monitor accounts and identify anomalies.

Enhance external oversight over budget implementation by setting up a committee (local government representatives and independent external observers, such as NGO representatives), to monitor budget implementation on a regular basis (i.e. each semester). Organize public debates/ forums to inform citizens about budget implementation. Adopt and implement a rigorous policy/procedure for tracking, receiving, securing, transferring and banking cash (including related authority and type of cash). Communicate it effectively. Provide adequate inception and continued training for officials involved. Separate duties regarding cash handling collecting, depositing and reconciling - so that one individual does not have responsibility for all activities. Restrict the number of officials involved in cash transactions. Adopt a clear delegation procedure to ensure only authorized persons deal with cash $^{14}$.

Detail of the amount of cash required for each good/service. Obtain maximal visibility of this price list. Promote use of electronic transactions processes in order to minimise the use of currency.

Ensure all cash handling processes are adequately documented and authorized (i.e. receipts for all payments received, including date/time of

\footnotetext{
${ }^{13}$ Слободяник Ю.Б. Розвиток державного аудиту // Актуальні проблеми економіки. 2011. № 5. C. $252-256$.

${ }_{14}$ Слободяник Ю.Б. Розвиток державного аудиту // Актуальні проблеми економіки. 2011. № 5. C. $252-256$.
} 
payment and amount). Ensure periodic check-ups, including mystery shoppers operations.

Introduce clear and comprehensive policy and procedures for payroll and disbursement of expenses and communicate them effectively (i.e. through intranet, internal meetings, instructions).

Ensure that only eligible officials have access to sensitive HR- and payroll-related information. Use access controls (passwords, routine verification procedures and authorisation). Where feasible, segregate functions to ensure that none has a complete control over any aspect of the payroll process.

Ensure mandatory advance approval by the supervisor for overtime and leave. Conduct unannounced spot checks by managers to verify attendance. Introduce a transparent and accountable system for the payment of monetary incentives.

Set clear instructions for claiming expenses (e.g. economy travel, accommodation, etc.). Adopt standardised rates on per diem paid.

Maintain adequate recordkeeping and reporting procedures to ensure that there are controls or systems to record and monitor all payroll transactions and all access to the payroll systems and actions taken are recorded.

\section{CONCLUSIONS}

Ever wonder which strategy do companies use for their financial benefit? As part of their strategic management plan, organizations implement various strategies to allocate resources more efficiently and reduce unnecessary expenses. They also check their financial statements regularly to identify losses and find new opportunities for growth and expansion. Financial controls play a key role in these processes.

At the most basic level, financial controls include the policies and processes that companies implement to ensure that their resources are properly monitored, directed and measured. These depend largely on the organization's size, industry and resources. A startup, for example, will have different financial controls than a multinational corporation.

In general, companies start with an initial analysis of their finances. During this stage, managers evaluate the cash flow statement, the balance sheet and profit and loss reports. Next, they simulate real-life situations and create forecasts to identify the main factors that may influence their revenue, expenditure and overall financial performance.

This information provides valuable insights based on which managers can develop policies and procedures to grow their business and reach their financial goals. It also helps ensure that everything is running 
well and can detect specific problems before they escalate. Furthermore, companies may use financial controls to implement preventive measures, determine the best course of action and identify areas of improvement.

\section{SUMMARY}

There are different types of control that organizations can use to ensure business growth and optimal performance. While financial controls focus on a company's finances and accounting procedures, strategic control involves setting performance standards, assessing and improving a company's current performance and setting goals for long-term business growth.

Your business may also implement operational control policies and procedures. The main difference between strategic control and operational control is that the first one helps track your strategy as it's being implemented, while the latter focuses on execution.

For example, operational control policies can help determine whether your company's resources are being utilized efficiently, the expenses associated with your new product line are in line with the cost estimates, your products meet the desired requirements and so on.

A strategic management plan can include different types of organizational controls depending on your company's short- and longterm goals. Financial controls, for example, can help you detect potential issues in your books and deviations in the budget. They also ensure that relevant accounting standards are implemented throughout the organization and that your business is operating efficiently. Strategic controls, on the other hand, can help you determine whether specific processes or strategies are working. The material used in the study has only the analysis of information resources.

\section{REFERENCES}

1. Багрінець С. Я. Діяльність міжнародних державних установ при здійсненні державного фінансового аудиту // Актуальні проблеми економіки. 2018. № 8. С. 321-334.

2. Богуславська В. С. Внутрішній контроль: міжнародна правктика // Вісник ЖДТУ.- Серія: Економічні науки. 2017. № 2. C. 84-92.

3. Вишнівська В. А. Організація міжнародного контролю: Монографія. К.: Поро, 2018. 256 с.

4. Войдевич Н. О. Розвиток державного внутрішнього фінансового контролю в Україні // Проблеми підвищення 
ефективності інфраструктури: Збірник наукових праць. Вип. 28. К.: НАУ, 2017. С. 26-29.

5. Вуйців М.М. Розвиток функції контролю при впровадженні інтегрованих інформаційних систем // Актуальні проблеми економіки. 2018. № 4. С. 226-242.

6. Гулько В.В. Модернізація державного фінансового контролю в Україні відповідно до європейського практики // Актуальні проблеми економіки. 2016. №1. С. 199-204.

7. Довбня В.Д. Внутрішній контроль: реалії часу: Монографія. Донецьк: УкрДон, 2013. 187 с.

8. Ковальчук С.Т. Внутрішній контроль: роздуми щодо сутності // Вісник ЧДТУ. 2017. №1. С. 11-17.

9. Кулаковська Л.П. Практичний погляд на фінансовий контроль та фінансовий менеджмент // Економіка і підприємництво. 2016. № 4. С. 14-19.

10. Марченко Д.М. Удосконалення організації внутрішнього фінансового контролю підприємств // Актуальні проблеми економіки. 2017. № 2. С. 163-171.

11. Нєскородєв Ю.В. Методологічні аспекти фінансового контролю: Монографія. К.: Фотос, 2015. 403 с.

12. Пожар Т.О. Роль фінансово-економічних методів державного фінансового контролю у забезпеченні бюджетної дисципліни // Актуальні проблеми економіки. 2011. № 8. С. 327-333.

13. Слободяник Ю.Б. Розвиток державного аудиту // Актуальні проблеми економіки. 2011. № 5. С. 252-256.

\section{Information about the author:} Bortnyak V. A.

Candidate of Science of Law, Assistant Professor, Assistant Professor at the Department of Constitutional and International Law of the Educational and Humanitarian Institute of the V. I. Vernadsky Taurida National University 33, Ivan Kudria str., Kyiv, Ukraine 